\title{
De overgang naar een Lean-management denk- en handelswijze
}

\author{
Vincent van Loenen, Roel Schouteten, Max Visser \& Ed Vosselman*
}

In deze studie bestuderen we de inpassing van Lean en beschrijven we wat er tijdens een vertaal- of inpassingsproces (ofwel 'translatie') van Lean bij een Nederlandse overheidsorganisatie gebeurt. 'Lean' wordt als een 'slanke' ofwel kostenbesparende en efficiënte handelswijze gezien. We analyseerden een Lean-inpassingsproces aan de hand van een Actor-Netwerk Theoretische analyse (ANT), die vier momenten van translatie onderkent: problematiseren, interesseren, toetreden en mobiliseren. Door praktijkinformatie uit deze casus te plaatsen in de translatiemomenten, zien we dat het Lean-inpassingsproces niet lineair en sequentieel verloopt. Deze ANT-beschrijving laat zien hoe zich rondom Lean een netwerk vormt, hoe Lean vormgeeft aan het netwerk, Lean zelf van vorm verandert, het Lean-netwerk uiteenvalt en hoe alsnog kleine en naast elkaar bestaande Lean-netwerken binnen één organisatie ontstaan.

\section{Inleiding}

Met een 'slanke' ofwel kostenbesparende en efficiënte handelswijze ('Lean' genaamd) bereiken organisaties substantiële verbeteringen (Womack \& Jones, 2003), wat verklaart waarom veel overheidsorganisaties de Lean-managementopvatting invoeren. Aangedreven door politieke en maatschappelijke eisen om tot flexibelere en transparantere overheidsorganisaties te komen (Anderson, 2018; Visser, 2016) kiezen ook overheidsmanagers voor Lean. Bij Lean-inpassingspogingen streven managers naar een efficiëntere en effectievere bedrijfsvoering waarmee zij hogere klantwaarde, kwaliteit van producten of dienstverlening leveren (Holmemo \& Ingvaldsen, 2018; Madsen, Risvik, \& Stenheim, 2017). Dit doen ze door toepassing van Lean-principes, -methoden en -technieken die organisatieleden stuurinformatie aanreiken om tot geoptimaliseerde bedrijfsvoeringprocessen te komen. Zodoende zien managers Lean als functioneel instrument dat hen ten dienste staat (Brunsson, 2006; Vosselman, 2014). Als gevolg hiervan voeren managers Lean vaak top-down, rationeel, ontwerpachtig en instrumenteel in, met een Lean-veranderprogramma als centrale verandermethode. Met deze inpassingsstrategie hopen managers dat organisatieleden Lean actief vertalen naar de eigen organisatiesituatie (Radaelli \& Sitton-Kent, 2016).

* Vincent van Loenen is als promovendus verbonden aan de Faculteit der Managementwetenschappen van de Radboud Universiteit. E-mailadres: v.vanloenen@fm.ru.nl. Roel Schouteten is als Assistent Professor en universitair docent strategisch personeelsmanagement verbonden aan dezelfde faculteit. Max Visser is als universitair hoofddocent management, accounting \& organisaties ook verbonden aan de Faculteit der Managementwetenschappen van de Radboud Universiteit. Ed Vosselman is als hoogleraar management accounting \& control eveneens verbonden aan deze faculteit. 
Wanneer we Lean-onderzoeksliteratuur erop naslaan, blijken inpassingspogingen veelal moeizaam te verlopen. Ze stranden vroegtijdig en blijken afhankelijk van de organisatiecontext waarin het organisatieconcept een plek krijgt (Colazo, 2018; Van Grinsven, 2017; Van Loenen, 2017). Bij Lean-inpassingen spelen verschillende factoren een belemmerende rol. Dit zijn factoren als de conceptuele onduidelijkheid van Lean, tekortschietende managementbetrokkenheid en -ondersteuning of niet aansluitende leiderschapsstijlen, matige Lean-opleidingen en inferieur verandermanagement (Ingvaldsen \& Benders, 2016; Van Loenen \& Schouteten, 2016). Door het managen van belemmeringsfactoren vergroten we de kans op een succesvolle Lean-inpassing (Liker, 2004; Nicolai \& Dautwiz, 2010; Madsen et al., 2017; McCann, Hassard, Granter \& Hyde, 2015; Marodin \& Saurin, 2015). Verder zien we dat Lean de laatste decennia geëvolueerd is naar iets ongrijpbaars, hetgeen inpassing ervan niet vereenvoudigt. Het concept blijkt algemeen en vaag omschreven, en er zijn vaak nieuwe conceptuele ideeën aan toegevoegd, die voor velen tot Lean lijken te behoren. Door de conceptuele ideeënmix is het concept moeilijk definieerbaar en blijkt er nauwelijks consensus over de exacte betekenis en inhoud (Benders, 2017; Benders \& Santbergen, 2007; Madsen et al., 2017).

De vraag rijst of de huidige Lean-onderzoeksliteratuur niet een te eenzijdige weergave biedt van wat Lean echt teweegbrengt. Ze lijkt een deel van de Leaninpassingsdynamiek te missen en schetst mogelijk een simplistisch beeld vanuit een rationeel instrumenteel perspectief. Dit perspectief suggereert dat een Leaninpassing lineair en relatief probleemloos verloopt als het een plek in een organisatie krijgt. Wanneer we echter een Actor-Netwerk Theoretisch (ANT) perspectief nemen, dan bestuderen we een Lean-inpassing anders dan gangbaar. De ANT kijkt vanuit een relationeel oogpunt. Dat wil zeggen dat het Lean als een 'actor' ziet die vorm krijgt en vormgeeft aan een netwerk. Het is dan een speler in een netwerk van relaties, verbindingen, interacties en associaties van menselijke en niet-menselijke actoren (Latour, 2005; Van Erp, Roozen, \& Vosselman, in press; Van Erp \& Van der Steen, 2018; Vosselman, 2014).

Dit artikel illustreert een relationele kijk op een Lean-inpassing. Dit perspectief kent geen volgtijdelijk stappenplan, maar ziet het proces van het inpassen van Lean als momenten van translatie die niet lineair, voorspelbaar en sequentieel verlopen. We presenteren resultaten van een praktijkgericht realtime onderzoek bij een Nederlandse overheidsorganisatie, die sinds 2009 Lean probeert in te passen. Centraal staat de vraag: hoe krijgt de actor Lean vorm en hoe geeft deze tevens vorm aan het netwerk waarin het een plek krijgt? Hiermee komen we tegemoet aan oproepen om een beter en genuanceerder beeld te geven van wat er gebeurt tijdens een Lean-inpassing. Want er blijkt met name gebrek aan empirische kennis over het verloop van een Lean-inpassingsproces: over hoe Lean vorm krijgt en van vorm verandert, en over hoe het proces van betekenis geven, construeren en onderhandelen van actoren in zijn werk gaat (Benders, 2017; Brännmark et al., 2012; Radaelli \& Sitton-Kent, 2016; Røvik, 2016; Van Grinsven, 2017). Een relationele bril biedt kans om diepere vertaalmechanismen en -dynamieken te tonen. 
Een rationele en relationele kijk op een Lean-inpassing

Bij bestudering van een Lean-inpassing vanuit rationeel perspectief zien we het concept als een functioneel instrument dat managers helpt bij het inrichten van een efficiëntere bedrijfsvoering gericht op klantvragen. Daarbij staan vijf principes centraal: (1) specificeren van klantwaarde, (2) identificeren van waardestromen, (3) creëren van flow (een constante stroom van producten en/of diensten langs bewerkingsstations) op basis van klantvraagvoorspelling, (4) maken op klantvraag, en (5) elimineren van verspillingen. Met deze principes beoogt Lean de productieof dienstverleningsarbeidsprocessen continu te optimaliseren, waarbij medewerkersparticipatie en -betrokkenheid van belang zijn (De Koeijer \& Hazelzet, 2017; Jones \& Womack, 2017; Madsen et al., 2017; Womack \& Jones, 2003). Hierbij geldt dat werknemersinspraak centraal staat binnen het gedachtegoed; verantwoordelijkheden komen lager in de organisatie te liggen, waardoor de organisatie ook platter georganiseerd kan worden (Benders, 2017; Womack \& Jones, 2003). Vanuit relationeel perspectief gaat de aandacht uit naar hoe menselijke en nietmenselijke actoren rondom Lean een netwerk vormen op basis van vier translatiemomenten en dit uitgroeit tot een robuust en duurzaam Lean-actornetwerk. Door toepassing van dit perspectief komen interactieprocessen en de performatieve werking van Lean aan het licht. Performativiteit betekent dat Lean over beïnvloedingskracht beschikt om de actoren in het netwerk en het netwerk zelf te veranderen. Wederzijdse beïnvloeding tussen menselijke en niet-menselijke actoren zorgt voor onverwachte effecten, waardoor een Lean-inpassing beperkt lineair en gering maakbaar is.

Het relationele perspectief staat hiermee haaks op het rationele perspectief (Van Erp \& Van der Steen, 2018). Bij een rationeel perspectief zien we managers als centrale besluitvormer die Lean top-down willen invoeren en dit insteken als stapsgewijs lineair proces. Het relationele perspectief concentreert zich op hoe Lean tijdens een inpassingsproces verandert, in een organisatie beweegt, actoren aan zich bindt, actoren aanzet tot handelen en de context waarin het een plek krijgt transformeert (Van Erp \& Van der Steen, 2018; Vosselman, 2014). Daarbij doorloopt een Lean-inpassing verschillende momenten van translatie, al dan niet in een bepaalde volgorde, omdat door organisatie- of netwerkontwikkelingen Lean-inpassingen kunnen 'terugvallen' naar eerder doorlopen translatiemomenten.

\section{De Actor-Netwerk Theorie}

Met de Actor-Netwerk Theorie (ANT) analyseren en beschrijven we heterogene sociaal-technische systemen: systemen die bestaan uit menselijke en niet-menselijke actoren in een netwerk. Hierbij concentreren we ons op hoe een netwerk zich vormt door netwerkeffecten zoals interactieprocessen, relaties, verbindingen en associaties tussen menselijke en niet-menselijke actoren. Net zoals mensen met elkaar verbindingen aangaan, gaat Lean als gevolg van haar performatieve werking verbindingen met mensen aan. Dat betekent dat Lean mensen aanzet tot handelen of daarvan af laat zien.

Bij de analyse van netwerkvorming, gaat de ANT uit van een symmetrisch veld van menselijke en niet-menselijke actoren. Dit symmetrieprincipe betekent dat de ANT geen onderscheid maakt tussen beide actoren. In analytische zin staan menselijke en niet-menselijke actoren op gelijk niveau (Callon, 1986; Latour, 1986, 2007; Law, 1992; Van Erp et al., in press). Pas als ze met elkaar interac- 
teren ontstaat er verschil in positie en ontstaat een lokale werkelijkheid ofwel netwerk. Dit werkelijkheidsconstruct is volgens de ANT vergankelijk omdat het 'slechts' een tijdelijke ordetoestand is. De ANT beschouwt de werkelijkheid als een resultante van continue netwerkeffecten op een bepaald moment, dat zich steeds verder ontwikkelt (Latour, 1987, 2005; Law, 1992, 2004; Rothfusz, 2017). Wanneer actoren het nut van de relaties en verbindingen niet meer inzien, kan het netwerk uiteenvallen. Door te focussen op netwerkeffecten kunnen we reconstrueren hoe actoren een netwerk vormen en inzicht krijgen in de kracht en macht van menselijke actoren en de niet-menselijke actor zoals Lean (Law \& Singleton, 2014). Symmetrie veronderstelt dat niet-menselijke actoren beïnvloedingskracht bezitten (Latour, 2005). Deze dimensie valt uiteen in twee aspecten: agency en performativiteit. Agency behoort toe aan menselijke actoren. Zij beïnvloeden elkaar, veranderen dingen en zetten zaken naar hun hand op basis van wil, intenties, preferenties en emoties (Callon, 1986; Latour, 2005; Rothfusz, 2017; Vosselman \& De Loo, 2018). Niet-menselijke actoren bezitten geen intentionaliteit (Callon, 1986). Zij bevatten performatieve werking, waardoor ze menselijke actoren mogelijk aanzetten tot handelen.

Actoren ordenen de werkelijkheid middels interactieprocessen die vorm krijgen in een translatieproces (Callon, 1980). Translatieprocessen houden in dat menselijke en niet-menselijke actoren samenkomen door een op macht gebaseerd translatieproces, ondanks verschillende belangen en interesses. Door een ANTanalyse zien we wie invloed uitoefent in het netwerk, welke actoren betrokken zijn en hoe de actor Lean vormgeeft aan netwerkverbanden en het netwerk vorm krijgt (Callon \& Latour, 1981; Law, 1992). Callon (1986) definieert het translatieproces in vier translatiemomenten: (1) problematiseren, (2) interesseren, (3) toetreding, en (4) mobilisatie. Bij het mobilisatiemoment is er sprake is van een stabiel geconstrueerd netwerk. Ondanks het bereiken van dit moment is het mogelijk dat het netwerk door netwerkeffecten 'terugvalt' in een eerder moment. Translatie-uitkomsten zijn daarom ongewis (Briers \& Chua, 2001).

Wanneer een actor erin slaagt andere actoren bij zijn idee aan te sluiten, dan noemen we deze een 'initiërende actor' (Callon, 1986). De initiërende actor fungeert hierbij als poortwachter (obligatory passing point; OPP), die een verplicht doorgangspunt is. De poortwachter zorgt ervoor dat in de problematiseringsfase actoren bijeenkomen rondom een probleem en door interactieprocessen bemiddelen over het probleem en mogelijke oplossingsrichtingen. Kortom: tijdens translaties kunnen geleidelijk aan diverse vormen van Lean in één organisatie ontstaan, wat kan leiden tot verschillende naast elkaar bestaande en soms overlappende lokale werkelijkheden (Law, 2004, 2009; Law \& Singleton, 2014; Rothfusz, 2017), wat Mol (2002) duidt met multipliciteit: veelvormigheid. Door beïnvloeding, (inter)actieprocessen en performativiteit verandert het netwerk, het ding en/of de organisatiecontext zelf.

\section{Onderzoeksopzet: dataverzameling en -analyse}

In deze gevalstudie is een Lean-inpassingsproces realtime bestudeerd bij een Nederlandse overheidsorganisatie die Lean sinds 2009 invoert. Deze overheidsorganisatie heeft geografisch verspreide organisatieonderdelen door het hele 
land, en heeft circa 9.000 werknemers. In 2009 experimenteerde de organisatie op lokaal niveau met Lean. Na een geslaagd lokaal experiment in 2009 past deze organisatie sinds 2012 Lean in de gehele organisatie in. Dit onderzoek concentreert zich op de vormgeving van het concept Lean, waarbij we zoeken naar verbindingen en relaties tussen Lean en menselijke actoren. We volgden de ontwikkelingen in een periode van 4 jaar tijd, waarmee we ook de continue verandering en performatieve werking van Lean in kaart konden brengen. Daarmee gaat deze studie over de grens heen van interpretatief onderzoek (Van Erp et al., in press).

We gebruikten drie datasoorten: semigestructureerde interviews, observaties en documenten. We analyseerden additionele documenten zoals Lean-inpassingsdocumenten op intranet, ondernemingsplannen, zoneborden op diverse afdelingen in de organisatie, beeldmateriaal (foto's) en cursusevaluaties. Ook woonden we als niet-participerende observant Lean-kennismakingsdagen, korte Lean-werkbijeenkomsten, dag-/weekstarts, en Lean-tentoonstellingen bij.

\section{Dataverzameling}

De dataverzameling bestond uit semigestructureerde interviews bij 38 informanten en besloeg een periode van 4 jaar, 2013-2016. De interviews duurden gemiddeld 60 minuten en zijn met toestemming opgenomen, na afname getranscribeerd en ter verificatie aangeboden. We interviewden 11 directeuren (D), 6 afdelingshoofden (AH), 11 medewerkers (M), 4 interne Lean-deskundigen (ILD), 2 externe Lean-deskundigen (ELD), 3 Lean Implementatie Teamleden (LIT) en 1 topconsultant (TC). We kozen voor deze informanten omdat zij allen nadrukkelijk met Lean te maken kregen. We interviewden directeuren omdat zij verplicht waren een Lean en dienend-leiderschapscursus te volgen. Afdelingshoofden bevroegen we omdat zij hun directeuren moesten ondersteunen. Tevens interviewden we in- en externe Lean-deskundigen omdat zij de Lean-inpassing moesten faciliteren en enkele Lean-implementatieleden (LIL) omdat zij de inpassing aanstuurden. Ook raadpleegden we medewerkers omdat zij te maken kregen met het inpassen van het concept. Sommige informanten raadpleegden we tweemaal omdat: (1) de eerste interviews of observaties daartoe aanleiding gaven, of (2) informanten gaandeweg intern van baan wisselden en daarmee soms dicht bij managementteams terechtkwamen, of (3) informanten de organisatie verlieten. In alle gevallen werd verondersteld dat deze wisselingen nieuwe en interessante inzichten zouden geven en dat bleek het geval. Verder voerden we een achttal niet-participerende observaties uit van gemiddeld 75 minuten. De aandacht ging uit naar wie bijdroegen aan Lean-initiatieven en hun motieven. We keken naar interacties zoals het betekenisgevingsproces van Lean, het gebruik van kleurtoekenningsprocessen bij zone- en visuele managementborden en het debat.

\section{Data-analyse}

Alvorens de data in het softwareprogramma Atlas.ti te analyseren is een conventietabel gemaakt waarin het kernbegrip (translatieproces) in dimensies (problematiseren, interesseren, toetreden en mobiliseren) is onderscheiden. Vervolgens zijn alle interviews (tekstfragmenten) in de momenten van translatie gecodeerd en voorzien van dimensie- en topic-codes. Daarbij maakten we aantekeningen over wat de codes en tekstfragmenten betekenen in het translatieproces. Op die 
wijze konden we inzicht krijgen in de interacties en verbindingen die leiden tot een netwerk waarin Lean een plek vindt. Bij het becommentariëren van tekstfragmenten waren we waakzaam om géén verklaringen te geven maar enkel een beschrijving over hoe een netwerk tot stand komt. De commentaren zijn vervolgens op dimensieniveau samengebracht, waardoor een verhaallijn ontstond over het translatieproces van Lean in deze casus. Ter voorkoming van interpersoonlijke subjectiviteit zijn belangrijke beslissingen ten aanzien van de coderingen en plaatsing van de codes gespiegeld aan inzichten van collega-onderzoekers en is discussie gevoerd over hoe we betekenis moesten geven aan actoren (Guest, Wright, \& Paauwe, 2012).

\section{Resultaten}

We analyseerden de data volgens de vier translatiemomenten. In de problematiseringsfase werd Lean geïntroduceerd en gekoppeld aan een probleem. In de interesseringsfase volgden we Lean en menselijke-actoren en hoe ze verbinding met elkaar leggen. In de toetredingsfase analyseerden we hoe het concept werd gebruikt en hoe dat gebruik tot succesverhalen leidde. In de mobilisatiefase concentreerden we ons op de wijze waarop interacties en verbindingen zich verenigden tot een homogene massa, daarbij lettend op de netwerkstabiliteit en op hoe de Lean-discussie (abstracte succes- en toepassingsverhalen) leidde tot nieuwe potentiële toetredingskandidaten.

\section{Problematiseringsfase en de initiërende actoren (2009-2012)}

De ANT ziet het aangaan en onderhouden van interacties in het netwerk als een continu en intensief proces. Dit is ook in deze casus terug te zien. De dataanalyse laat zien dat in de problematiseringsfase drie verschillende factoren een rol speelden bij de introductie en adoptie van Lean. Ten eerste spoorden politieke en maatschappelijke krachten overheidsorganisaties aan tot een effectievere en efficiëntere dienstverlening. De minister wilde een kleinere organisatie en het topmanagement wilde hier invulling aan geven. Dit deed dat door middel van drie ondernemingsplannen: 2004-2008, 2008-2012 en 2012-2015, met in het laatste plan een nadrukkelijke verwijzing naar Lean als oplossing voor een efficiëntere en effectievere organisatie (AH11, ILD1, LIT3 en AH4). Dit kwam niet in de laatste plaats doordat de toenmalige minister het concept kende vanuit een vorige arbeidscontext. Ten tweede ondervond een organisatieonderdeel in het midden van het land interne organisatieproblemen. Mensen werkten in silo's en kwamen nauwelijks tot in- en externe klantwaarde. Ook werden productieafspraken niet gehaald. Dit gold organisatiebreed, maar een afdelingshoofd in het midden van het land wilde hier wat aan doen. Ten derde speelde een externe organisatieadviseur een prominente rol: in 2009 adviseerde hij Lean toe te passen als oplossing voor het afdelings-/organisatieprobleem dat het afdelingshoofd ervoer. Op deze manier ontstond een pilotlocatie op een afdeling in het midden van het land.

'Ik wilde veranderen langs de inhoud van het werk omdat medewerkers dan meer betrokken raken omdat de inhoud centraal staat en niet het gewenste gedrag. (...) 
We wilden ook dat medewerkers hun eigen werk optimaliseerden en als gevolg daarvan ontstaat het gewenste gedrag. Lean lijkt op deze gedragsverandering het beste in te spelen, zo liet ik mij adviseren (...) Medewerkerscapaciteit benutten en ze ruimte bieden om klantwaarde te leveren en arbeidsproces te optimaliseren door hen te empoweren. Bovendien ben ik van mening dat een verandering dan beter zal beklijven' (Initiator).

De initiator (een toenmalig afdelingshoofd) vroeg drie belangrijke naaste medewerkers een onderzoek te doen of Lean in de organisatie zou passen. Na een Lean-literatuurstudie, bedrijfsbezoek bij Scania en discussies met elkaar, startte in 2009 een lokaal Lean-experiment. Hiermee interesseerde de initiator anderen om toe te treden tot het rondom het probleem gevormde netwerk, waardoor het netwerk expandeerde. De initiator en de consultant fungeerden als initiërende actoren. Ze konden drie nauw betrokken personen aan zich binden en vormden gevijven de initiërende actoren. Er vormde zich een netwerk ondanks een aantal tegengeluiden. Meer menselijke actoren sloten zich aan bij het lokale netwerk dat uit Lean en 15 personen bestond. De initiërende en aangesloten actoren zagen het algehele organisatieprobleem, ervoeren het en koppelden probleem en mogelijke oplossing aan elkaar. Ze waren ontvankelijk en zagen de voordelen van het middel. Zij wilden een netwerk configureren om het probleem op te lossen en gebruikten daarvoor de niet-menselijke actor Lean. Het probleem, de menselijke- en niet-menselijke actoren fungeerden als poortwachter. Samen interesseerden ze andere actoren voor het concept en zetten ze aan om ermee te oefenen. Zo legden ze verbindingen tussen elkaar en met Lean. Een steeds groter wordende groep associeerde zich met het concept en na verschillende projecten slaagden ze erin om middels Lean organisatieverbeteringen te bewerkstelligen. $\mathrm{Zij}$ slaagden na 3 jaar oefenen met Lean het lokale vergunningsverleningsproces te optimaliseren. Daarmee werd de Lean-pilot een succes.

Dit succes leidde in 2012 tot de start van de landelijke uitrol. Lean kreeg daarbij een prominente plaats in het ondernemingsplan met een ambitieus toepassingsdoel. In 3 jaar moest Lean binnen de gehele organisatie in de genen van de medewerkers zitten en daarmee onomkeerbaar zijn. Erg ambitieus, aldus de initiator en nauw betrokkenen bij het Lean-experiment, omdat mensen in het organisatieonderdeel van de pilotlocatie 3 jaar konden oefenen met het concept en er destijds ook zeker projecten mislukten. Alleen hoorde je hier niemand over (AH11, ILD1, LIT2, en AH5). Desondanks toont het concept zijn beïnvloedingskracht en zien we een Lean-actornetwerk dat landelijk vervolg krijgt.

De landelijke uitrolfase I (2012)

In de beginfase van de landelijke uitrol verliep de inpassing voorspoedig. Meer mensen interesseerden zich voor het probleem en de oplossing. De gelaagde Lean-proef leidde tot de oprichting van een Lean Implementatie Team, Leanopleidingen en tot Lean-practitioners en -deskundigen. Voorts werden Leanervaringsdagen, Lean-werkbijeenkomsten, Lean-tentoonstellingen en ideeënmanagement ontwikkeld. Om de Lean-inpassing echt kracht bij te zetten moesten leidinggevenden naar een cursus 'Lean en dienend leiderschap'.

De initiërende actoren konden potentieel nieuwe actoren overtuigen zich aan te sluiten bij het uitdijende netwerk en Lean toonde zijn beïnvloedingskracht. 
Zodoende werden allerlei middelen ingezet om het concept te promoten en de bijdrage aan te tonen. Veelvuldig verkondigden actoren die als eerste succes behaalden met Lean hun succesverhaal en wat het kan opleveren. We kunnen hen nu ook zien als initiërende actoren en poortwachters. In het begin van het translatieproces konden steeds meer organisatieleden zich met het concept identificeren. Het efficiënter werken door verspillingen te elimineren en klantwaarde te leveren sprak velen aan en klonk logisch. Vele informanten associeerden Lean steevast met het elimineren van verspillingen, leveren van klantwaarde en continu verbeteren door arbeidsprocesoptimalisaties met medewerkersparticipatie en -empowerment.

Uit de data-analyse blijkt dat Lean-praktijkbeoefenaars of Lean-deskundigen, maar ook lijnmanagers zich aanmelden om een Lean-cursus te volgen. Dat deden zij door de aantrekkingskracht van het concept, maar veelal ook omdat hun huidige functie op de tocht stond. Tegelijk met de Lean-introductie, kondigde de organisatie namelijk een reorganisatie aan.

'De aangekondigde reorganisatie zorgde voor een min of meer gedwongen aansluiting bij de Lean-groep en had vooral een groot window-dressing-gehalte' (ILD1 en LIT1).

Aangevoerd door de initiërende actoren werden 37 interne Lean-praktijkbeoefenaars en -deskundigen opgeleid en trokken zij met het Lean-verhaal en -methoden door het land. Gewapend met zilveren koffers en stiften ontpopten zij zich als echte ambassadeurs van het concept. Ze vertelden het Lean-verhaal en faciliteerden voornamelijk managementteams bij het opstellen van brown papers en het opzetten van visuele management- en zoneborden. Verspreid over het land ontstonden diverse Lean-activiteiten en bloeide Lean op. Het concept leidde vooral tot andere overlegstructuren door de inzet van visuele managementen zoneborden. Diverse directeuren, afdelingshoofden en lijnmanagers raakten overtuigd van de kracht van het concept en droegen dat ook uit. Het netwerk met meer en meer toetredende actoren breidde zich uit.

Slechts enkelen, zo blijkt uit de data, bleken oprecht enthousiast, voornamelijk Lean-deskundigen. Al snel ontstond ook inhoudelijke en hiërarchische kritiek. Met name de top-downbenadering, de instrumentele toepassingswijze, de beperkte toepasbaarheid en het ontbreken van organisatorische beweegredenen maakte dat organisatieleden op alle niveaus zich niet in Lean konden vinden.

Het 'zaadje' dat de initiatiefnemers in 2009 plantten (het idee, het verhaal achter het idee, wat zij met het idee willen bereiken) en het succes van de doorlooptijdverkorting omtrent vergunningaanvragen bleken niet als vliegwiel te fungeren. Slechts enkele mensen kenden de echte beweegredenen van het Lean-initiatief. Intern bleken managers er een eigen Lean-verhaal op na te houden dat afweek van de eigenlijke bedoelingen. Bovendien koppelden organisatieleden en voornamelijk managers het meedoen met Lean vooral aan persoonlijke doelen (baanbehoud). Daarbij bleek dat het Lean-gedachtegoed als fundament fragiel is.

'Ik ben te vroeg weggegaan bij de experimentlocatie. (...) Ik denk dat je minimaal 5 jaar sturing moet geven aan een Lean-ontwikkeltraject omdat het een traject is van lange adem. (...) Je ziet na mijn vertrek dat het Lean-verhaal en de interesse afbrokkelt. Terwijl ik dacht dat het robuust was. (...) De zaadjes die we elders in de organi- 
satie planten ontkiemen niet omdat de top en andere managementteams niet begrepen waarom het echt gaat' (Initiator).

In deze periode bleken zich tevens andere Lean-translatieproblemen voor te doen. Er bleek een aanzienlijke mismatch tussen wat medewerkers moesten doen om klantwaarde te leveren en wat het management dacht dat daarvoor nodig was. Het leidde tot wederzijds onbegrip en verscheidenheid aan Lean-uitingen. De mate van abstractie in het concept bleek de translatie parten te spelen. Met name hoe te komen tot in- en externe klantwaarde bleek een moeilijk aspect. Bovenal wist het management zich geen raad met hoe zij het takenpakket van medewerkers concreet op die klantwaarde en procesgerichte benadering zou kunnen richten. Velen vonden het te abstract en moeilijk toepasbaar.

'De crux zit in het koppelen en concreet maken van klantwaarde en vervolgens de organisatie daarop inrichten (...) Dat laatste ligt voor de hand omdat Lean daarom vraagt en het in de tijdsgeest past. Procesgerichte organisaties blijken nu eenmaal een sleutelwoord en dat ligt politiek handig' (D11).

In deze interesseringsfase stelden mensen opnieuw onderhandelingsvragen. Vooral leidinggevenden bleken niet als een poortwachter te kunnen functioneren terwijl dit het beoogde doel leek. Hiermee verdween een deel van de problematisering. Actoren waren nadrukkelijk op zoek naar hoe het concept te gebruiken en vroegen een verdieping op het succesverhaal. Ze wilden de voordelen inzien en zich mogelijk aansluiten. Dergelijke onderhandelingsvragen werden bij het Lean Implementatie Team, de Lean-praktijkbeoefenaars en -deskundigen als vervelend ervaren.

'In het Lean Implementatie Team is al helemaal geen ruimte voor kritiek. Lean moet een succesverhaal worden. (...) Bovendien bestaan er binnen het Lean Implementatie Team verschillende visies over Lean dat de uniforme communicatie niet ten goede komt' (ILD1).

Dat organisatieleden mogelijk toetraden tot het netwerk bleek uit intervisies die Lean-praktijkbeoefenaars en -deskundigen met elkaar hadden. Ze deelden ervaringen, uitdagingen en dilemma's, en keken hoe ze Lean-praktijkproblemen gezamenlijk konden oplossen. De data laten zien dat mensen problemen ondervonden met hoe Lean te gebruiken. Ook hadden zij moeite met de door het management toegevoegde ideeën die het concept meer hybride maakten. Additieven als 'de managementtrechter' (Vandendriessche \& Clement, 2010) en 'dienend leiderschap' werden toegevoegd, waarmee het management de Lean-translatie wilde opstuwen. Actoren die anderen probeerden over te halen vertelden geen eenduidig verhaal. Bovendien bleek er van alles bijgehaald te worden wat Lean in deze organisatie, in de interesseringsfase, nog verwarrender maakte. Zo voegden sommigen dienend leiderschap toe, ketenorganisatie, procesgerichte arbeidsprocessen en zelfsturende teams.

'Omdat we niet eens weten wat de basisgedachte van Lean is kunnen we er überhaupt geen invulling aan geven. Laat staan een concrete vertaling maken naar je dagelijkse 
praktijk. (...) Het blijft steken op zone- of visuele managementborden en onafgemaakte brown-papersessies' (M7).

'De toevoeging van dienend leiderschap is eenzelfde verhaal. Na een cursus denken we hier invulling aan te kunnen geven. Niets is natuurlijk minder waar. (...) Daarmee denken we aan Lean te doen' (M3 en M1).

Daarnaast voelde de landelijke inpassing voor nagenoeg alle organisatieleden als abrupt en top-down ingestoken. Op de initiërende actoren na, wisten organisatieleden niet waarom de organisatie Lean introduceerde en met welk doel. De 'negatieve' Lean-connotatie - het realiseren van personele krimp, dezelfde productie leveren met minder mensen en een politieke bezuinigingstaak verwezenlijken - was snel gelegd. Verscheidenheid aan beeldvorming over het concept, verschillende verhaallijnen en de mogelijk onduidelijke bijdrage van Lean zorgden ervoor dat mensen niet wisten waar ze zich aan (ver)bonden. Op dit moment leek het netwerk dat zich sinds de landelijke uitrol ontvouwde, uiteen te vallen. De initiator merkt op:

'En dan zie je dat we het niet goed aanpakken. Voor velen is Lean te ingewikkeld. Mensen begrijpen het concept, de redenering en de inpassing ervan niet. Er ontstaat veel ruis en het is voor velen te abstract. Mensen voelen zich niet met Lean verbonden en connectie naar het eigen werk kunnen ze niet maken.'

De val van het netwerk (begin 2013)

De aangekondigde reorganisatie in het ondernemingsplan van 2012-2015, waarin Lean een prominente plaats had, leidde tot het uiteenvallen van het bestaande Lean-netwerk. De organisatie werd een plattere en procesgerichte ketenorganisatie, waarin 'producten' via een constante stroom langs diverse bewerkingsstations (mensen) gaan. Op 1 april 2013 was de reorganisatie een feit en raakten mensen uit het initiële netwerk (implementatieteam) over het land verspreid. Veel organisatieleden kregen een andere functie en/of kwamen in een ander organisatieonderdeel te werken waardoor de Lean-implementatie naar een dieptepunt zakte.

Managers van weleer, Lean-deskundigen en -praktijkbeoefenaars waren 'gewone' organisatieleden geworden en het netwerk waarin zij zaten bestond niet meer. Het leidde tot versnipperde Lean-kennis en mensen raakten elkaar kwijt, waardoor Lean-kennis niet veel meer werd ingezet. Lean-deskundigen of -praktijkbeoefenaars werden niet meer geraadpleegd. Bovendien gaven Lean-deskundigen en -praktijkbeoefenaars invulling aan deze functie naast hun eigenlijke werk. Bovenal wisten veel nieuwe managers niet waarom ze met Lean moesten werken en zagen zij de voordelen er niet van in. Daardoor bleken zij niet in staat het Lean-netwerk verder uit te bouwen, maar concentreerden zij zich op de formatie van nieuwe afdelingen. De actoren zagen de belangen om met Lean aan de slag te gaan niet meer en daardoor verviel de behoefte om het netwerk in stand te houden.

'De reorganisatie heeft Lean enorm tekortgedaan' (M2, D2, ILD1, 2 en 5, D5). 
De landelijke uitrolfase II (2014)

Het Lean Implementatie Team zag in 2014 met lede ogen aan hoe de Lean-inpassing vast kwam te zitten. Opnieuw begon een problematiserings-, interesserings- en toetredingsfase.

'Kijk, het gaat moeizamer dan verwacht. We trekken vaak aan een dood paard. In sommige gevallen zijn we nog geen millimeter vooruitgekomen' (LIT1).

Het Lean Implementatie Team wilde de Lean-inpassing vlot trekken. Middels formele afspraken wilden ze grip krijgen op de inpassing en dit leek vruchten af te werpen. Sommige leidinggevenden stuurden actief en dit neigde naar een 'gedwongen' fase van interesse en toetreden. Nieuw geplaatste leidinggevenden volgden allen een opleiding 'Lean en dienend leiderschap'. Ook moesten leidinggevenden sturen op het afronden van 350 verbeteracties, voortkomend uit brownpapersessies uit fase I. Ondanks dat medewerkers nog steeds niet altijd een gezamenlijk beeld van probleem en oplossing hadden, traden ze door andere argumenten toe tot het netwerk. Een lijnmanager liet mensen bijvoorbeeld verplicht naar Lean-dagen en Scania gaan, of stuurde op allerlei Lean-methoden. Door gebruik van de methoden verplicht te stellen en medewerkers hiervoor te belonen, hoopten managers anderen te overtuigen van de voordelen van het concept en hen over te halen zich aan te sluiten bij het netwerk. Managers fungeerden daarmee 'gedwongen' als poortwachter. Dat leek te kloppen, omdat sommigen aangaven dat de werving van mensen met een Lean-achtergrond leidde tot een korte inpassingsopleving. $\mathrm{Zij}$ stimuleerden en zorgden voor herijking van referentiekaders, en zone- en visuele managementborden.

'We creëerden een prikkel en stimulans om met Lean te werken. Je ziet sinds de komst van de nieuwe directeuren dat Lean toch een beetje opleeft' (AH5).

Ook in deze fase bleek er sprake te zijn van getemperd enthousiasme en kritiek. Uit de data-analyse blijkt dat veel hooggeplaatste directeuren te dicht bij het topmanagement zaten om er niets mee te doen. 'Ze kunnen gewoon niet anders' (AH1, D9 en D2). Managers op lagere niveaus deden aan Lean omdat ze moesten, maar kenden niet de overtuiging dat het concept in deze casus werkt. Ook in 2015 ging enkel nog het succesverhaal van 2009 rond.

'Wat ik mis is een kritische noot, het zijn vooral de oude successen die ze tonen en niet de problemen. Waar liepen ze tegen aan bij het gebruiken van Lean. Dat zou helpen in het elkaar opzoeken en verbonden voelen met lotgenoten' (M6).

De landelijke uitrolfase III: de kleine netwerkjes (2015)

In 2015 kwamen verspreid door het land verschillende Lean-activiteiten aan de oppervlakte. Lean was op diverse plekken en onafhankelijk van elkaar gearriveerd in de organisatie; niet als volledig ingevoerd concept, maar fragmentarisch op diverse plekken. We zien daarbij veel verschillen in Lean-toepassingen, vooral bij de zone- en visuele managementborden, die onderdeel zijn geworden van de dagelijkse gang van zaken. 
'Ik kan alleen maar bevestigen dat we veel verschillende borden hebben. Die heeft dit, de ander heeft dat. Groen en rijp door elkaar. (...) Maar als het voor hen werkt. Wat moet je er dan van zeggen'? (AH5).

Ondanks de moeizame netwerkvorming bleken voormalig Lean-practitioners, Lean-deskundigen en managers hun werk met het Lean-gedachtegoed te optimaliseren. Een voormalig afdelingshoofd gaf aan dat zijn projectteam dingen anders aanpakt, bijvoorbeeld door te vergaderen middels een zonebord en projectresultaten visueel te presenteren in plaats van in dikke rapporten. Dit resoneert met een beeld dat Heusinkveld en Benders (2012) presenteren. Ondanks dat een Lean-adaptie tegenvalt of beoogde resultaten er niet komen, sedimenteren de methoden en technieken uit het gedachtegoed op een of andere manier. Omdat organisatieleden ermee in aanraking waren gekomen, konden ze er gefragmenteerd gebruik van maken. Succesvoorbeelden zijn het verkorten van de doorlooptijd van een wijzigingenproces van 8 maanden naar 1 maand, en het gebruik van visuele managementborden die dienen als stuurinformatie. Maar ondanks dat er verschillende Lean-werelden in één en dezelfde organisatie bestonden, leek het concept niet echt aan te slaan. Sinds november 2017 is het begrip Lean als zelfstandig element van intranet verdwenen, waardoor haar rol als poortwachter afnam.

\section{Discussie}

De bijdrage van dit paper is gelegen in de gedetailleerde beschrijving van een Lean-translatieproces, gebruikmakend van een relationeel onderzoeksperspectief. Onderzoek vanuit dit perspectief komt zelden voor (Van Grinsven, 2017) en is niet eerder uitgevoerd bij overheidsorganisaties (Niezink, Diepemaat, van Tiel, \& Ruijters, 2017). Met dit onderzoek leveren we inzicht in translatiedynamieken die bij rationeel onderzoek veelal buiten schot blijven. Hierdoor verrijken we ons inzicht in hoe Lean vorm krijgt en van vorm verandert, welke werking ervan uitgaat, en hoe het proces van betekenisgeven, construeren en onderhandelen van actoren in zijn werk gaat in een specifieke organisatiesituatie.

Uit deze gevalstudie blijkt dat de werkelijkheid rondom een Lean-translatie dynamischer verloopt dan gedacht wordt vanuit een rationele benadering. Netwerkeffecten en de performatieve werking van Lean zijn effecten die velen niet voor mogelijk houden en in rationele onderzoeken niet worden bestudeerd. Een relationele kijk op een Lean-inpassing leert ons dat het concept tot bepaalde handelingen aanzet, waardoor een Lean-translatie en de context waarin Lean een plek krijgt vele kanten op kunnen gaan. Effecten waar we vooraf lastig rekening mee kunnen houden. Dit betekent dat we het rationele perspectief, dat uitgaat van een maakbaarheidsprincipe (Van Oss \& Van 't Hek, 2009), wellicht moeten loslaten en meer moeten (be)sturen vanuit translatiedynamiek.

De politieke en maatschappelijke eisen gaven richting aan het besluit om het concept te implementeren. Echter, hier bleef het niet bij. Lean bleek meer dan een middel en ontpopte zich gaandeweg tot een invloedrijke speler in het netwerk. Uit deze case blijkt hoe menselijke actoren en de niet-menselijke actor 
Lean elkaar aantrekken. We zien binnen het perspectief van Latour (2005) dat initiërende actoren anderen overtuigen van Leans 'probleemoplossingskracht' en hoe ontvankelijke actoren zich aansluiten bij het concept en het geformuleerde probleem. Een fenomeen dat Brunsson (2006) ook beschreef in zijn verhandeling over waarom managers organisatieconcepten zien als mechanisme van hoop en inzetten als probleemoplosser. Deze studie bevestigt dit verschijnsel. Tevens zien we netwerkeffecten, zoals aansporingen door initiërende actoren, externe adviseurs en Lean. Deze fungeerden als verplicht passeerpunt. Zoals Callon (1986) beschrijft: met het poortwachtersprincipe ontmoeten Lean en menselijke actoren elkaar. Initiërende actoren kozen zorgvuldig ontvankelijke actoren om met het concept problemen aan te pakken en het Lean-verhaal te verkondigen. Het zorgvuldig kiezen van actoren blijkt een 'gouden' zet. Menselijke actoren en het concept (ver)binden heterogeniteit aan gebruikers door toepassing van narratieven, gesterkt met één succesverhaal. Lean kreeg vorm en vormde de lokale pilotorganisatie. Hierbij blijkt er voldoende ruimte voor verdiepen in, verwonderen over en overtuigen van de kracht van Lean, wat een cruciale stap is in de netwerkvorming (Latour, 2004). We zien hoe Lean identiteit verwierf en het netwerk door interacties geleidelijk expandeerde.

Niet alleen externe beïnvloedingsmechanismen als consultancy en bedrijfsbezoeken leidden tot netwerkvorming. Het topmanagement bleek gebiologeerd door Leansuccessen van elders. Lean kreeg daardoor steeds meer invloed. Zo zette Lean hen aan tot het streven naar een efficiënte en effectieve organisatie, wat leidde tot een herontwerp waarin deregulatie, reductie van managementlagen, medewerkersparticipatie en -empowerment een rol speelden. Van Leans beïnvloedingskracht (performativiteit) bleken managers en andere organisatieleden zich nauwelijks bewust. Geleidelijk aan ontstond een tunnelvisie; een top-downinpassing van het instrument dat moest slagen. Dergelijk handelen lijkt het gevolg van een voorprogrammering van Lean. Een conditioneringseffect in de hunkering naar efficiëntie.

We zien dat we Lean als actor en menselijke actoren niet los van elkaar kunnen zien (Latour, 2005). Managers hielden weinig rekening met het effect van de organisatiecontextwijzigingen voor diverse organisatieleden en de organisatie zelf. De managementinterventie - de reorganisatie naar een ketenorganisatie en een andere organisatiestructuur - leidden tot onherstelbare schade in de netwerkvorming. Geconstrueerde relaties, verbindingen en interacties werden verbroken, waardoor het gevormde netwerk aan kracht verloor en instabiel werd. Waar in de beginfase Lean een vanzelfsprekendheid leek, kwam het concept later ter discussie te staan. Door herinterpretaties, associaties en vertaalmoeilijkheden, versterkt door agency en performativiteit, kwam de managementinterventie tot stilstand.

De performatieve werking en translatiedynamiek van Lean variëren afhankelijk van de plek binnen de organisatie. Later zien we verschillende vormen van Lean in diverse lokale netwerken, ook wel multipliciteit genoemd. Dit is een empirische aanvulling op theoretische inzichten van Mol (2002) en Law \& Singleton (2014). De geografisch verspreide actoren bleken in staat op basis van interessewerking nieuwe kleine lokale netwerken te vormen. Ze trokken nieuwe, geïnteresseerde actoren aan en mobiliseerden hen. In deze netwerkjes transleerden ze de inhoud 
van Lean naar een voor hen werkbare toepassing en dit leidde bijvoorbeeld tot een diversiteit aan zone- en visuele managementborden.

In die lokale netwerkjes destilleren we drie soorten actoren. Het eerste type actor voelt zich oprecht aangetrokken tot het concept en het organisatieprobleem. Deze actor handelt in overeenstemming met het te realiseren organisatiedoel. De tweede actor lijkt zich weinig aan te trekken van die organisatiedoelen en handelt voornamelijk vanuit particulier belang. Deze ziet het als persoonlijk voordeel om iets met het concept te doen. Deze actor schetst een parallelle werkelijkheid, waardoor het lijkt alsof hij of zij meedoet met de rest van de organisatie. De derde groep actoren, voornamelijk managers, handelt vanuit management(groeps)druk. Zij doen mee omdat topmanagers dit van hen verlangen.

\section{Conclusies}

Dit artikel laat de performatieve werking van Lean zien, en dat een Leaninpassing door translatiedynamieken beweeglijker verloopt dan vanuit rationele inpassingsstrategieën gedacht wordt. Topmanagers dachten in Lean een bondgenoot te vinden bij het aanpakken van organisatieproblemen en ze dachten dat de Lean-inpassing tevens een antwoord zou geven op externe wensen. De gedachte van het management om met een planmatig aangestuurde Leaninpassing de organisatie efficiënter en klantgerichter te maken, waarbij ze tevens tegemoetkomt aan externe wensen, blijkt in de praktijk tegen te vallen. De studieresultaten laten zien dat netwerkeffecten zich lastig laten beteugelen. Enkel een rationele top-downinpassing lijkt een heilloze zaak vanwege de geringe programmeerbaarheid. Lean blijkt niet enkel een instrument dat zich laat vormen door mensenhanden. Lean blijkt een speler die vorm krijgt en vormgeeft aan een netwerk. Bovendien biedt de plasticiteit en conceptuele onduidelijkheid van het concept ruimte voor nieuwe betekenissen die het lastig maken grip te krijgen op translatiedynamieken. Translatieprocessen kennen uiteenlopende en onverwachte effecten die eraan bijdragen dat er verschillende Lean-netwerken in één organisatie naast elkaar kunnen bestaan (Callon, 1998; Callon, Lascoumes, \& Barthe, 2011; Mol, 2002; Van Erp et al., in press).

Naast dat organisatieleden aanzienlijk worstelden met het inpassen van het concept in hun organisatiecontext, vraagt een inpassing van Lean een andere houding van het (top)management. Leans performativiteit en netwerkeffecten tijdens een translatieproces laten zien dat het op afstand managen van een Leaninvoering middels een rationeel volgtijdelijk stappenplan niet langer opportuun is. Willen managers meer 'controle' krijgen op translatiedynamieken tijdens een Lean-inpassing, dan lijken zij er goed aan te doen om te participeren tijdens de interactieprocessen, zodat ze een inpassing in de beoogde richting kunnen sturen (Van Oss \& Van 't Hek, 2009). Want zelfs wanneer het netwerk vanzelfsprekend lijkt, kan de mobilisatiekracht onvoldoende zijn om een netwerk van enige betekenis in stand te houden. Op elk willekeurig moment kan het netwerk door netwerkontwikkelingen terugvallen in een eerder translatiemoment, dat translatieuitkomsten ongewis maakt (Briers \& Chua, 2001). 


\section{Onderzoekreflectie}

Hoewel we met een enkelvoudige casestudie niet kunnen generaliseren (Tsang, 2013), dragen we bij aan theoretische generalisatie of aanscherping binnen de Lean-inpassingsstudies. Met deze studie verrijken we bestaand studiemateriaal, omdat Lean-inpassingsmateriaal uit overheidsorganisaties nog niet bestaat (Benders, 2017; Drotz, 2014; Niezink et al., 2017; Van Grinsven, 2017). Bovendien is het beschouwen van Lean als netwerkspeler binnen de Lean-inpassingsliteratuur zeer zelden gehanteerd. Meer onderzoek vanuit een ANT-analyse zou een verhelderend beeld kunnen geven van wat er gebeurt als organisaties Lean inpassen. Dat lijkt noodzakelijk omdat de meeste inpassingspogingen vroegtijdig stranden. Willen we meer weten over Leans performatieve werking en translatiedynamieken, zodat toekomstige inpassingspogingen een grotere kans van slagen hebben, dan moeten we in vervolgonderzoek rekening houden met een aantal ANT-aspecten.

Zo uiten sommige auteurs kritieken over welke actoren te volgen tijdens onderzoek. De ANT stelt dat door de keuze en focus op bepaalde actoren relaties vanzelf naar boven drijven wanneer de verbindingen gemaakt zijn. Dit suggereert dat relaties duidelijk zijn, maar dat is volgens McLean \& Hassard (2004) twijfelachtig. Onderzoekers moeten zich er bewust van zijn dat actoren alleen die interacties prijsgeven die zij zelf relevant vinden. Dus waar rationeel onderzoek mogelijk geen compleet beeld geeft van wat er gebeurt tijdens Lean-inpassingen, geeft relationeel onderzoek dit mogelijk ook niet. Dat komt omdat gedurende het onderzoek gekozen wordt voor het volgen van een bepaalde actor in het netwerk. Hierdoor missen we mogelijk een groot deel van de ontwikkelingen die zich elders (of verderop in het netwerk, buiten het gezichtsveld van de onderzoeker) afspelen. Bovendien bepaalt de onderzoeker welke actoren hij relevant vindt, gebaseerd op assumpties. Door het kiezen van invloedrijke actoren en goed naar hen te luisteren hebben we getracht deze bias te voorkomen. Verder zijn er kritieken op het symmetrieprincipe. In werkelijkheid is er altijd sprake van asymmetrie. Mensen en dingen bevatten nu eenmaal eigenschapen die vooraf vaststaan of worden toegedicht. Lean bezit op voorhand al macht (Holmemo, Rolfsen, \& Ingvaldsen, 2018), wat op gespannen voet staat met het symmetrieprincipe. Kortom, agency en performativiteit kunnen van buiten het netwerk komen en voor verschil in positie zorgen (Van Erp et al., in press).

Om onze kennis over Lean-translatiedynamieken te verrijken lijkt relationeel onderzoek een waardevolle aanvulling op rationeel onderzoek. Relationeel onderzoek biedt namelijk volop mogelijkheden om de performatieve werking van Lean in de praktijk te onderzoeken. Onderzoek hieromtrent staat nog in de kinderschoenen (Van Grinsven, 2017) en we weten nog nauwelijks wat er gebeurt tijdens een translatieproces. Door Lean te volgen in het netwerk, kan inzichtelijk worden gemaakt welke werking dit sorteert en hoe actoren handelen als gevolg van Leans performatieve werking. Ook kunnen we met relationeel onderzoek reflecteren op de consequenties van rationeel top-downhandelen van managers.

Praktische implicatie

Deze Lean-translatiestudie heeft praktische implicaties voor managers van organisaties. Vanuit rationeel oogpunt lijkt het logisch dat managers een Lean- 
translatie naar hun hand willen zetten. Managers passen Lean veelal top-down in en beschouwen Lean als een functioneel middel. We zien vanuit relationeel oogpunt echter dat Lean managers beïnvloedt in het streven naar een ideologische Lean-wereld die managers helpt op efficiënte en effectieve wijze klantwaarde te leveren. We zien ook dat managers zich automatisch buitenspel plaatsen wanneer zij een dergelijke inpassing top-down (be)sturen. Juist netwerkeffecten vragen om actieve participatie. Het (de)centraal aansturen van een Lean-implementatie leidt tot een schijnbare controle die niet lijkt te passen bij een dynamisch en chaotisch verloop van een Lean-translatie. Deze studie maakt duidelijk dat managers niet langer mogen verzuimen actief deel te nemen, waarbij ze gebruikmaken van vertaaldynamieken in plaats van dat ze proberen te bedwingen. Enkel actieve participatie helpt managers herinterpretaties en associaties in de gewenste richting (bij) te sturen in een zoektocht naar nieuwe samenhang.

\section{Literatuur}

Anderson, R. (2018). De implementatie van opgavegericht werken binnen gemeenten. Maandblad voor Accountancy en Bedrijfseconomie, 92(5/6), 167-175.

Benders, J. (2017). Lekker lean werken? Tijdschrift voor Arbeidsvraagstukken, 33(2), 215217.

Benders, J., \& Santbergen, S. (2007). 'Lean' in Nederlandse ziekenhuizen. M\&O Tijdschrift voor Management en Organisatie, 61(2), 36-47.

Brännmark, M., Langstrand, J., Johansson, S., Halvarsson, A., Abrahamsson, L., \& Winkel, J. (2012). Researching lean: Methodological implications of loose definitions. Quality innovation prosperity, 35-47.

Briers, M., \& Chua, W. F. (2001). The role of actor-networks and boundary objects in management accounting change: A field study of an implementation of activity-based costing. Accounting, organizations and society, 23(6), 237-269.

Brunsson, N. (2006). Mechanisms of hope: Maintaining the dream of the rational organization. Copenhagen: Copenhagen Business School Press.

Callon, M. (1980). Struggles and negotiations to define what is problematic and what is not: The sociology of translation. In K. D. Knorr, R. Krohn, and R. D. Whitley (Eds.), The social process of scientific investigation: Sociology of the sciences yearbook. Vol. 4 (pp. 197-219). Dordrecht: Reidel.

Callon, M. (1986). Some elements of a sociology of translation: Domestication of the scallops and the fishermen of St Brieuc Bay. The Sociological Review, 32(S1), 196-233.

Callon, M. (1998). An essay on framing and overflowing: Economic externalities revisited by sociology. The Sociological Review, 46(S1), 244-269.

Callon, M., \& Latour, B. (1981). Unscrewing the big Leviathan: How actors macrostructure reality and how sociologists help them to do so. In K. D. Knorr-Cetina (Ed.), Advances in social theory and methodology: Toward an integration of micro-and macro-sociologies (pp. 277-303). Boston: Routledge \& Kegan Paul.

Callon, M., Lascoumes, P., \& Barthe, Y. (2011). Acting in an uncertain world: An essay on technical democracy. Cambridge, MA: The MIT Press.

Colazo, G. (2018). The change in communication patterns in teams implementing lean. Proceedings of the 51st Hawaii International Conference on System Sciences (pp. 217224). San Antonio, TX, USA: Trinity University.

De Koeijer, R., \& Hazelzet, J. (2017). Wat is nodig voor duurzame implementatie van Value Based Healthcare? Tijdschrift voor Arbeidsvraagstukken, 33(2), 199-213.

Drotz, E. (2014). Lean in the public sector: Possibilities and limitations. Linköping University, Department of Management and Engineering. Linköping: LiU-Tryck.

Guest, D., Paauwe, J., \& Wright, P. (2012). HRM and performance: Achievements and challenges. Padstow: John Wiley \& Sons. 
Heusinkveld, S., \& Benders, J. (2012). On sedimentation in management fashion: An institutional perspective. Journal of Organizational Change Management, 25(1), 121142.

Holmemo, M. D.-Q., \& Ingvaldsen, J. A. (2018). Local adaption and central confusion: Decentralized strategies for public service Lean implementation. Public Money \& Management, 38(1), 13-20.

Holmemo, M. D.-Q., Rolfsen, M., \& Ingvaldsen, J. A. (2018). Lean thinking: Outside-in, bottom-up? The paradox of contemporary soft lean and consultant-driven lean implementation. Total Quality Management \& Business Excellence, 29(1-2), 148-160.

Ingvaldsen, J. A., \& Benders, J. (2016). Lost in translation? The role of supervisors in lean production. German Journal of Human Resource Management, 30(1), 35-52.

Jones, D. T., \& Womack, J. P. (2017). The evolution of lean thinking and practice. In T. H. Netland \& D. J. Powell, The Routledge companion to lean management (pp. 3-8). Taylor \& Francis Group.

Latour, B. (1986). The powers of association. In J. Law (Ed.),, Power, action, and belief: A new sociology of knowledge (pp. 261-277). Londen: Routledge and Kegan Paul.

Latour, B. (1987). Science in action: How to follow scientists and engineers through society. Cambridge. Massachusetts: Harvard university press.

Latour, B. (1999). On recalling ANT. The Sociological Review, 47(S1), 15-25.

Latour, B. (2004). Politics of nature. Cambridge: Harvard University Press.

Latour, B. (2005). Reassembling the social: An introduction to actor-network-theory. Oxford: Oxford University Press.

Law, J. (1992). Notes on the theory of the actor network: Ordering, strategy and heterogeneity. Systems Practice, 5(4), 379-393.

Law, J. (2004). After method: Mess in social science research. New York: Routledge.

Law, J. (2009). Actor network theory and material semiotics. In B. S. Turner (Ed.), The new Blackwell companion to social theory, 3rd edition (pp. 141-158).. Oxford: Blackwell.

Law, J., \& Singleton, V. (2014). ANT, multiplicity and policy. Critical Policy Studies, 8(4), 379-396.

Liker, J. (2004). The Toyota Way: 14 Management Principles from the World's Greatest Manufacturer. New York: McGraw-Hill.

Madsen, D. Ø., Risvik, S., \& Stenheim, T. (2017). The diffusion of lean in the Norwegian municipality sector: An exploratory survey. Cogent Business \& Management, 4(1), 1411067.

Marodin, A. G., \& Saurin, T. A. (2015). Managing barriers to lean production implementation: Context matters. International Journal of Production Research, 53(13), 39473962.

McCann, L., Hassard S, J., Granter, E., \& Hyde J, P. (2015). Casting the lean spell: The promotion, dilution and erosion of lean management in the NHS. Human relations, 68(10), 1557-1577.

McLean, C., \& Hassard, J. (2004). Symmetrical absence/symmetrical absurdity: Critical notes on the production of actor-network accounts. Journal of Management Studies, 41(3), 493-519.

Mol, A. (2002). The body multiple: Ontology in medical practice. Durham: Duke University Press.

Nicolai, A., \& Dautwiz, J. (2010). Fuzziness in action: What consequences has linguistic ambiguity of the core competence concept of organizational usage? British Journal of Management, 21(4), 874-888.

Nicolini, D. (2010). Medical innovation as a process of translation: a case from the field of telemedicine. British Journal of Management, 21(4), 1011-1026.

Niezink, D., Diepemaat, M., van Tiel, P., \& Ruijters, E. (2017). Lean: van hype naar verbetercultuur. Deventer: Vakmedianet.

Radaelli, G., \& Sitton-Kent, L. (2016). Middle managers and the translation of new ideas in organizations: A review of micro-practices and contingencies. International Journal of Management Reviews, 18(3), 311-332.

Rothfusz, J. (2017). Potensia denkgereedschappen voor het werk met marginale groepen (Proefschrift). Groningen: Universiteit van Groningen. 
Røvik, K. A. (2016). Knowledge transfer as translation: Review and elements of an instrumental theory. International Journal of Management Reviews, 18(3), 290-310.

Tsang, E. (2013). Case study methodology: Causal explanation, contextualization, and theorizing. Journal of International Management, 19, 195-202.

Van Erp, W., Roozen, F., \& Vosselman, E. (in press). Management accounting as a relational ontology: relational agency, performativity and multiplicity. Accounting, Auditing \& Accountability Journal.

Van Grinsven, M. (2017). 'A patient is not a car' Lean in healthcare: Studying agency in the translation of management concepts (Proefschrift). Amsterdam: Universiteit van Amsterdam.

Van Loenen, V. (2017). Inzet van management-controlinstrumenten: Grip op de dynamiek van een Lean-implementatie. M\&O Tijdschrift voor Management en Organisatie, 71(6), 4-25.

Van Loenen, V., \& Schouteten, R. (2016). Implementatie van lean; inzicht in inertiefactoren. M\&O Tijdschrift voor Management en Organisatie, 70(2), 20-37.

Van Oss, L., \& Van 't Hek, J. (2009). On veranderbaarheid van organisaties. Amsterdam: Mediawerf.

Van Erp, W., \& Van der Steen, M. (2018). De performativiteit van accounting in de gezondheidszorg. Maandblad voor Accountancy en Bedrijfseconomie, 92(1/2), 37-45.

Vandendriessche, F., \& Clement, J. (2010). Leiding geven zonder bevelen. Schiedam: Scriptum.

Visser, M. (2016). Management Control, Accountability, and Learning in Public Sector Organizations: A Critical Analysis. Governance and Performance in Public and Non-Profit Organizations, 75-93.

Vosselman, E. (2014). The 'performativity thesis' and its critics: Towards a relational ontology of management accounting. Accounting and Business Research, 44(2), 181203.

Vosselman, E. (2016). Accounting, accountability, and ethics in public sector organizations: Toward a duality between instrumental accountability and relational response-ability. Administration \& Society, 48(5), 602-627.

Vosselman, E., \& De Loo, I. (2018). Performativiteit in netwerken: de Januskop van accounting. Maandblad voor Accountancy en Bedrijfseconomie, 92(1/2), 21-25.

Womack, J. P., \& Jones, D. T. (2003). Lean thinking. banish waste and create wealth in your corporation. Londen: Free Press Edition.

Womack, J. P., Jones, D. T., \& Roos, D. (2007). The machine that changed the world. New York: Simon and Schuster. 